\title{
Is early grass harvest for silage an overlooked reason for skylark Alauda arvensis population decline in Sweden?
}

\author{
Är tidig höskörd för ensilering en förbisedd orsak till sånglärkans Alauda arvensis \\ beståndsnedgång i Sverige?
}

\author{
JAN SONDELL, JULIE MURRAY \& MAGNUS PERSSON
}

\begin{abstract}
In 2015 we studied the relative importance of silage and cereal crops as breeding habitat for the skylark Alauda arvensis. In 2014 we had found that skylarks failed to breed successfully in grass silage fields. We compared skylark density between crops in one organic and one conventional farm, c. 100 ha each, at Kvismaren valley in south Sweden (approx. $59.2^{\circ} \mathrm{N} ; 15.4^{\circ} \mathrm{E}$ ). The densities were similar in all crops: 83 territories $/ \mathrm{km}^{2}$ in silage and 75 (spring sown) or 80 (autumn sown) in cereal. However, silage harvest in early June and July destroyed, as in the previous year, almost all nests, effectively preventing skylarks from reproducing successfully in that habitat. Cereal fields are not harvested until after the young

are fledged. Approximately $45 \%$ of the farmland area in Sweden is grass for silage, normally harvested in late May or early June. We suggest that this early harvest is an important and overlooked driver for population decline of birds nesting in such fields.

Jan Sondell, Rulleuddsvägen 10, S-178 51 Ekerö. Email:jan.sondell@telia.com

Julie Murray, 1 Farm Cottage, Leckmelm Farm, Loch Broom, Ullapool, Ross-Shire, IV23 2RH Scotland. Email: murray.ecology@gmail.com

Magnus Persson, Husön, Bärsta 708, S-715 92 Stora Mellösa.E-mail: humlapersson@hotmail.com
\end{abstract}

Received 23 November 2015, Accepted 28 Arpil 2016, Editor: R. Ekblom

\section{Introduction}

The skylark Alauda arvensis is abundant all over Europe on intensively used farmland, natural pasture and coastal meadows. It is the only passerine breeding directly on the ground in open fields away from scrub and tree which may be used as observation posts for predators. In recent years the population trend in Europe has been classified as "decreasing". The causes are not fully known, but it is probable that there is a combination of factors behind the decline (BirdLife International). Intensive farming is a major threat, along with reduction of suitable habitat, and predation is also a limiting factor. In England small mammals are major predators (Morris et al. 2008, Buckingham et al. 2015) whilst in other parts of Europe raptors and corvids predominate (Praus \& Weidinger 2010).

The skylark is still the twentieth most common bird species in Sweden (Ottosson et al. 2012). It is found on open grassland almost all over the country. However, the Swedish Bird Survey (Green et al. 2016) shows a decrease in recent decades.
Since 2015 the species has been classified as NT (Near Threatened) in the Swedish Red List (ArtDatabanken 2015). Possible reasons for this are the declining farming area and the increasingly more intensive use of grassland, where the first harvest nowadays is done at the end of May or early June in central Sweden. This early cut, that will have a detrimental impact on all species dwelling in the grass, is little discussed in Sweden today and may be an overlooked driver for skylark population decrease in Sweden, despite the phenomenon being reported from many other parts of Europe (Buckingham et al. 2015, Donald 2004, Grüebler et al. 2012, Kuiper et al. 2015, Jenny 1990, Vickery 2001).

The study presented here was conducted on arable land in the Kvismaren valley (approx. $59.2^{\circ} \mathrm{N}$; $\left.15.4^{\circ} \mathrm{E}\right)$. The population is relatively dense and the species is one of the most common in the Kvismaren area. Another similarly ground nesting bird in the area is the ortolan bunting Emberiza hourtulana, but unlike the skylark it is one of the rarest breeding birds in the valley. Both species share the 
same nesting habitats in grassland or cereal fields. Research looking into explanations for the ortolan decline (Sondell et al. 2011) found that problems caused by the use of pesticides may be one of several possibilities. Analysis of blood samples from young birds is a method that can be used to test this theory. However, the ortolan bunting is a highly vulnerable species and ground disturbance caused by searching for their nests can lead to an increased risk of stress and predation. Blood tests on skylark chicks may provide an alternative benchmark for assessing the levels of pesticides in passerine species living on farmland in the area.

When searching for skylark nests in 2014 to obtain blood samples, we observed that all nests on a large grass field used for silage production were destroyed by the first harvest, taking place on 27 May. To learn more about the situation, we decided to carry out a survey of skylarks in 2015 .

\section{Objectives}

The aim of this study was to assess the effects of farming techniques on breeding skylarks in farmland at Kvismaren. The common crops in the area were represented: grassland (harvested for silage), and autumn and spring sown cereals. Conventional and organic farmland were compared in order to find out whether there were any significant differences in population densities.

\section{Methods}

Two large farms were chosen with similar location and ground conditions, essentially humus soil created by drained marshland. Most of the fields in the plain landscape are sown in spring because of the risk for ice lift of the roots of small growing plants sown in the autumn. The conventional farm, using pesticides, is Bärsta and the organic farm is Sörby. Only Sörby has silage fields, as a breeder of cattle for milk production. All fields within the study area

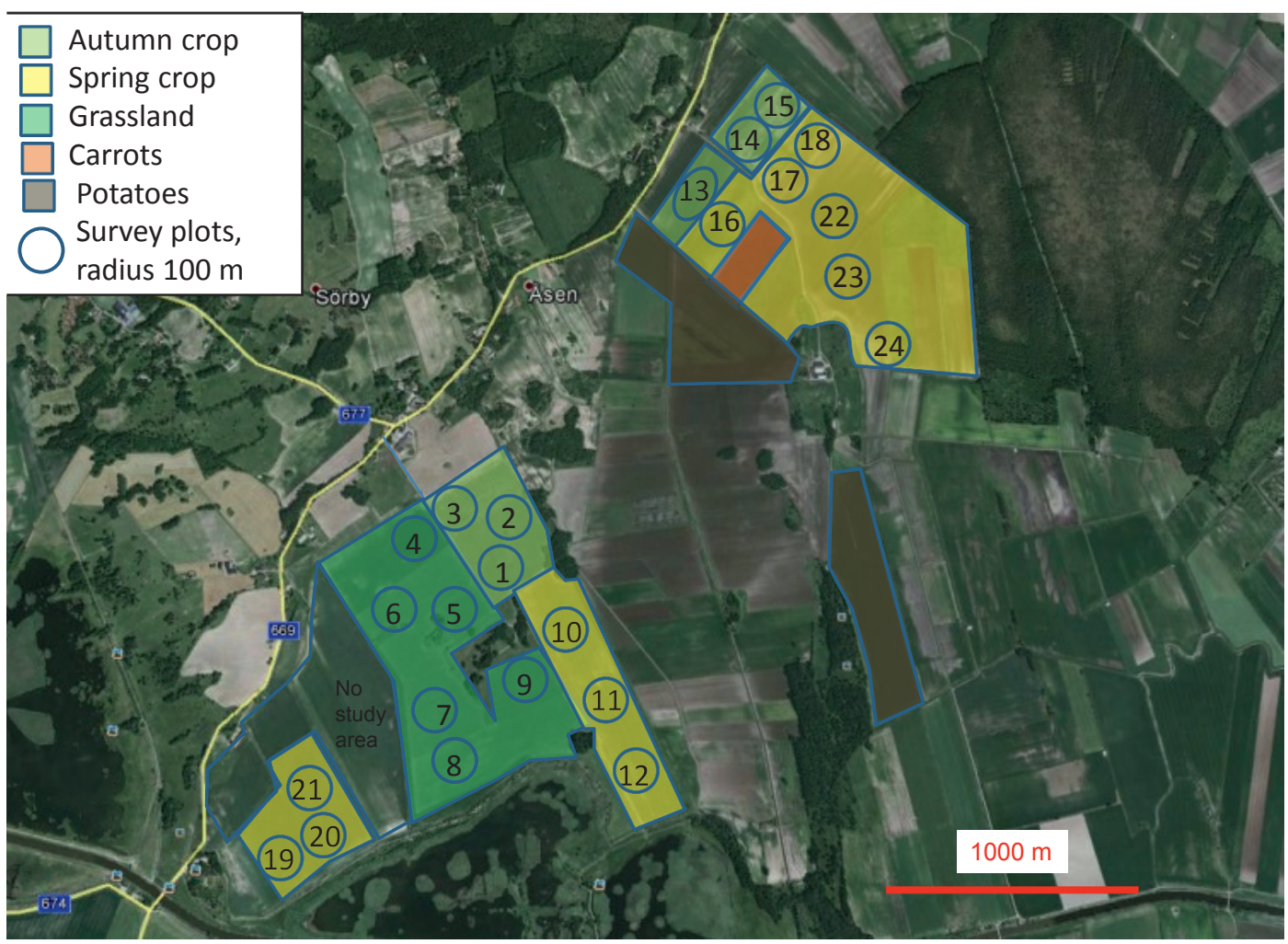

Figure 1. Part of the Kvismaren valley with survey plots on fields belonging to the Bärsta (top NE) and Sörby estates (bottom $\mathrm{SW})$. (From Google maps.)

Del av Kvismardalen med provytor på fält som tillhör Bärsta (i NO) och Sörby (i SV) gårdar. 
Table 1. Number of survey plots 2015 at Kvismaren in different kinds of crop and approximate plot and field areas in hectares (ha).

Antal provytor 2015 i Kvismaren i olika grödor och ungefärliga arealer på provytor och åkerfält $i$ hektar (ha).

\begin{tabular}{|c|c|c|c|c|c|c|}
\hline \multirow[b]{2}{*}{ Crop Gröda } & \multicolumn{3}{|c|}{ Bärsta estate (conventional) } & \multicolumn{3}{|c|}{ Sörby estate (organic) } \\
\hline & $\begin{array}{c}\text { Number } \\
\text { of plots } \\
\text { Antal } \\
\text { provytor }\end{array}$ & $\begin{array}{l}\text { Total plot } \\
\text { area, } \approx \text { ha } \\
\text { Total } \\
\text { provyta }\end{array}$ & $\begin{array}{l}\text { Total field } \\
\text { area, } \approx \text { ha } \\
\text { Total } \\
\text { fältarea }\end{array}$ & $\begin{array}{c}\text { Number } \\
\text { of plots } \\
\text { Antal } \\
\text { provytor }\end{array}$ & $\begin{array}{c}\text { Total plot } \\
\text { area, } \approx \text { ha } \\
\text { Total } \\
\text { provyta }\end{array}$ & $\begin{array}{l}\text { Total field } \\
\text { area, } \approx \text { ha } \\
\text { Total } \\
\text { fältarea }\end{array}$ \\
\hline Autumn grain Höstsäd & 3 & 9 & 20 & 3 & 9 & 20 \\
\hline Spring grain Vårsäd & 6 & 18 & 70 & 6 & 18 & 40 \\
\hline Grassland Vall & - & - & - & 6 & 18 & 50 \\
\hline Sum & 9 & 27 & 90 & 15 & 45 & 110 \\
\hline
\end{tabular}

were large and bordered other fields. The total area is some 200 hectares. Few trees or tree islets were present in the neighborhood (Figure 1).

In total 24 circular plots (Table 1) of 100 metre radius (3.14 ha) were marked out on a map of the fields at the two farms (Figure 1). Each plot was surveyed regularly throughout the season (11 May, 26 May, 10 June, 25 June, 10 July), including preand post- silage harvest. Each plot was visited for 15 minutes, including 5 minutes at the beginning to allow the birds to settle after the surveyor had walked up to the centre point (see Photo 1). Thus no activity was recorded in these first 5 minutes. During the following 10 minutes, all observations of singing skylarks were recorded on a plan of the plot, including flight lines if possible - the birds were sometimes singing so high up that mapping their exact movements was difficult. Birds holding territories on the borders of the plots were counted as 0.5 territories. The fieldwork was conducted by Elisabeth Kopp (EKP), Julie Murray (JMY) and Magnus Persson (MPN). Before the start of the survey it was checked that all fieldworkers were counting and recording in a similar manner. This was done by each surveying the same plot and comparing results. The height of the vegetation was measured using a 1 meter long stick held horizontally at the 'mean' top, judged by eye, of the actual stalks. The distance to the ground was then measured.

It was desirable to know a little about the nesting period, firstly to check the breeding stage and secondly to collect blood samples for analyses of pesticides. Therefore, we carefully searched for nests during and immediately after harvest in 2014 and 2015 and also recorded potential predators as well as studying their behavior. Furthermore, in 2015 we randomly searched the fields for replacement clutches in the new growth of grass, during the post-harvest period.
To get information of the breeding period for skylarks in the part of Sweden where Kvismaren is located (Svealand; $58-61^{\circ} \mathrm{N}$ ), accessible ringing data from 1962-2001 at the Swedish Bird Ringing Centre was analysed together with ringing data from Kvismaren 2014 and 2015.

\section{Results}

\section{Vegetation height}

The mean vegetation height at different dates during the survey period is presented in Figure 2 and Appendix 1. On 22 May the autumn crop (wheatrye hybrid triticale at both farms) was $35 \mathrm{~cm}$ high while the spring crop (wheat at Bärsta, oats at Sörby) had not yet reached $10 \mathrm{~cm}$. By mid-May the autumn sown cereals were already taller than the grass, which did not gain much more height by late May-early June. The grassland was harvested for the first time on the 5 and 9 June (harvester breakdown in between), the vegetation being cut down to a height of around $10 \mathrm{~cm}$. The grass had reached

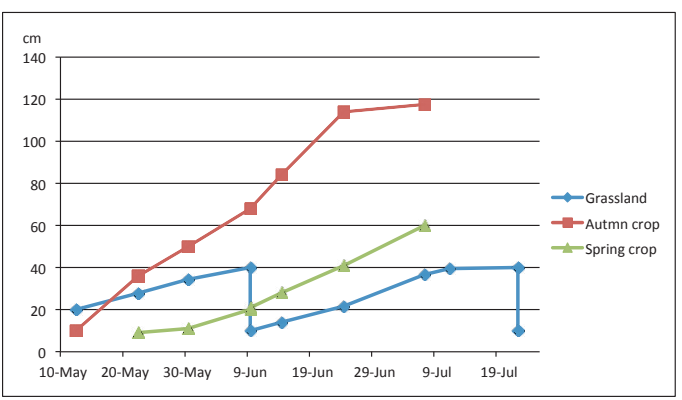

Figure 2. Mean vegetation heights in the various crops of fields included in the skylark study May-July 2015.

Medelhöjd på vegetationen i olika grödor som ingick $i$ studien av sånglärka maj-juli 2015. 
Table 2. Compilation of survey result 2015 at Kvismaren in different kinds of crop. The result is based on two inventory rounds per crop in May for autumn seed and silage and two rounds in late May early June for spring crop. Territories per plot including standard deviation and territories per hectares are given including mean number of territories per type of crop.

Inventeringsresultat i olika grödor baserat på två inventeringsomgångar. Antal revir per provyta med standardavvikelse per hektar redovisas, även revir i medeltal per gröda.

\begin{tabular}{|c|c|c|c|c|c|}
\hline $\begin{array}{l}\text { Crop } \\
\text { Gröda }\end{array}$ & $\begin{array}{c}\text { Inventory } \\
\text { dates } \\
\text { Inventerings- } \\
\text { dagar }\end{array}$ & $\begin{array}{c}\text { Territories } \\
\text { per plot } \\
\text { Revir } \\
\text { per provyta }\end{array}$ & $\begin{array}{l}\text { Standard } \\
\text { deviation }\end{array}$ & $\begin{array}{c}\text { Territories } \\
\text { per hectare } \\
\text { Revir } \\
\text { per hektar }\end{array}$ & $\begin{array}{l}\text { Mean per } \\
\text { type of crop } \\
\text { Medeltal per } \\
\text { typ av gröda }\end{array}$ \\
\hline \multicolumn{6}{|c|}{ Autumn grain Höstsäd } \\
\hline Sörby & $12+22$ May & 2.75 & 1.35 & 0.92 & \multirow{2}{*}{0.80} \\
\hline Bärsta & 15+24 May & 2.00 & 1.05 & 0.67 & \\
\hline \multicolumn{6}{|c|}{ Spring grain Vårsäd } \\
\hline Sörby & 31 May+14 June & 2.08 & 1.61 & 0.69 & \multirow{2}{*}{0.75} \\
\hline Bärsta & 31 May+15 June & 2.44 & 0.53 & 0.81 & \\
\hline \multicolumn{6}{|l|}{ Silage Vallodling } \\
\hline Sörby & $12+22$ May & 2.50 & 1.31 & 0.83 & 0.83 \\
\hline Average Medeltal & & & & 0.80 & 0.79 \\
\hline
\end{tabular}

$40 \mathrm{~cm}$ again by 11 July when the final survey round was completed. The second cut of the silage field was done 22 July, delayed by roughly a week due to wet weather. By the end of June both autumn and spring seed were higher than the grass. Later in the season a third harvest of silage was carried out on 23 September.

\section{Survey of skylark territories and timing of} breeding in Sweden

In Table 2 the survey result is summarized (see also Appendix 1 for the full dataset). There was no

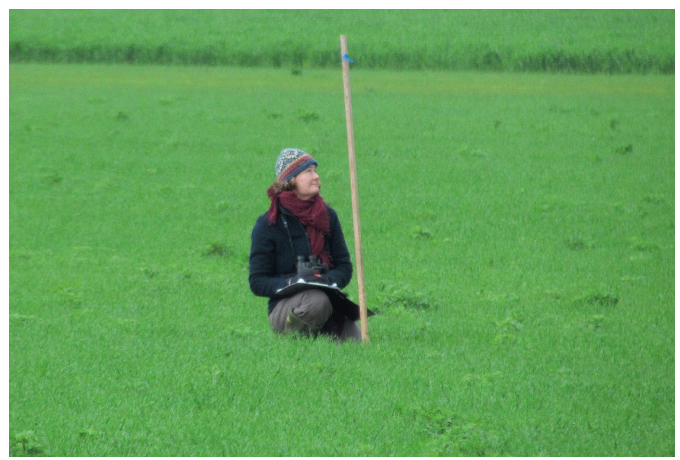

Photo 1. Julie Murray is counting the singing skylarks at a survey plot in spring seed. Kvismaren 30 May 2015.

Julie Murray räknar sjungande sånglärkor på en inventeringspunkt den 30 maj 2015. Foto Jan Sondell. significant difference in skylark numbers between the conventional and organic farms ( $\mathrm{t}$-test, autumn seed $\mathrm{t}=0.76, \mathrm{df}=6, \mathrm{p}>0.2$ and spring seed $\mathrm{t}=0.52$, $\mathrm{df}=6, \mathrm{p}>0.2$ ). The survey result shows almost the same density of territories in different types of crop at the end of May ( $p>0.2$ for all combinations of grass and grain). A mean of $0.75-0.83$ territories per hectare (autumn seed 0.80 , spring seed 0.75 and grassland 0.83 ) or $75-83$ territories per $\mathrm{km}^{2}$ was registered based on the two rounds showing the highest number of singing males. In the spring grain at Sörby however the variation was high (mean 2.04, std. dev. 1.61 territories per plot, Table

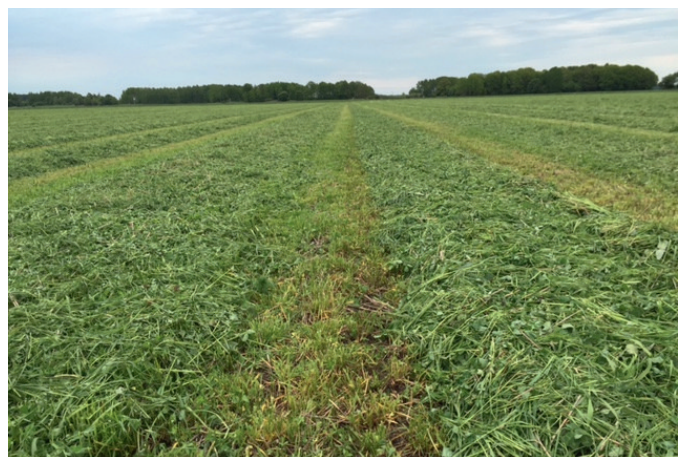

Photo 2. Newly cut silage field at Sörby estate, Kvismaren in the beginning of June 2016.

Nyingen skördat ensilagefält på Sörby gård, Kvismaren $i$ början av juni 2016. Foto Magnus Persson. 

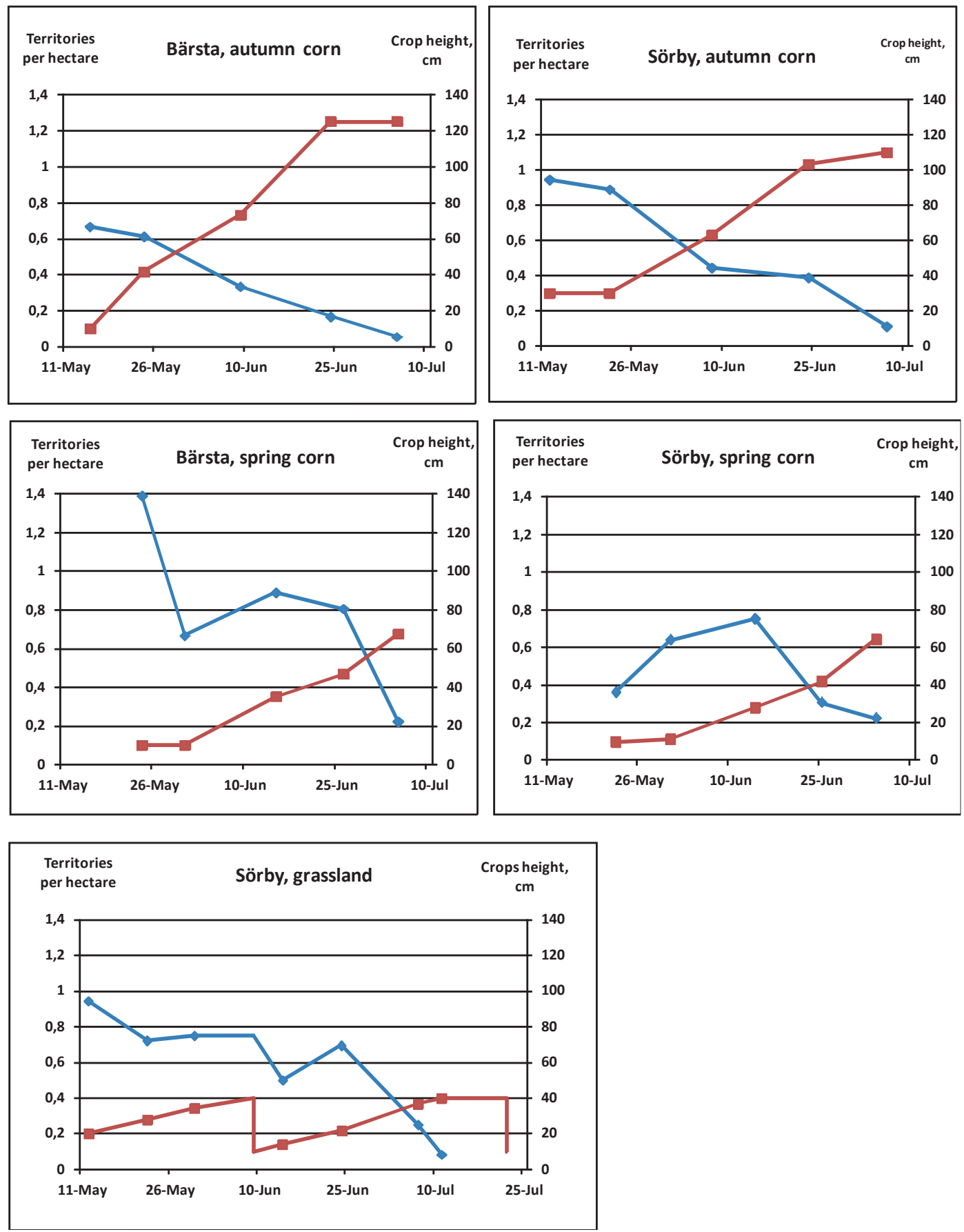

Figure 3. Skylark territories (blue) at different survey date and crop height (red) in different crops. In grassland there are two dips in crop height indicating the two harvests, on 5 or 9 June, and 22 July (note that data for 9 and 22 June are approximations). The second harvest was delayed by one week due to rain.

Antal revir (blå) av sånglärka vid olika stråhöjd (röd) i olika grödor vid olika inventeringstillfällen. I vallodlingen indikerar det två nedgångarna skördetillfällena den 5 eller 9 juni respektive 22 juli (notera att data för 9 och 22 juni är uppskattningar). Den andra skörden var försenad på grund av regn. 


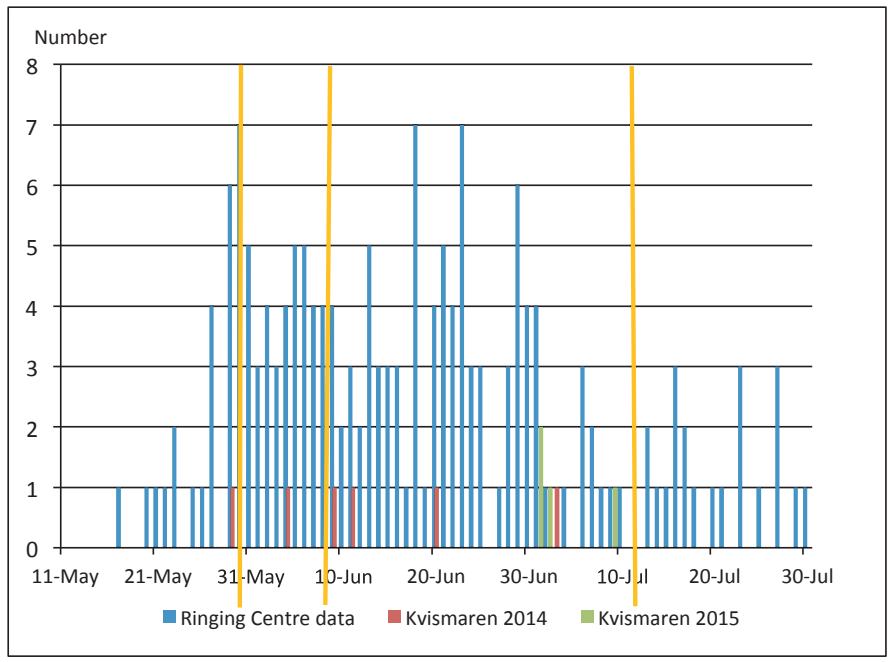

Figure 4. Ringing dates for skylark clutches 1962-2001 in Svealand from Swedish Bird Ringing Centre. Yellow vertical bars show in order (1) early to normal first harvest of silage 2014, (2) late first harvest in 2015 and (3) late second harvest in 2015. Clutches spontaneously ringed at Kvismaren in 2014 and 2015 are also indicated.

Datum för ringmärkning av kullar av sånglärka 1961-2001 i Svealand enligt Ringmärkningscentralen. Gula vertikala streck visar $i$ ordning tidigt till normalt skördetillfälle 2014, sen första skörd 2015 och sen andra skörd 2015. Kullar som tillfälligtvis har märkts vid Kvismare fägelstation 2014-2015 visas också.
$2)$. This was probably partly due to the islets with tall trees in close proximity and partly due to the bordering silage field (Figure 1).

Number of skylark territories in grassland cut for silage at Sörby at different height of crop is also shown in Figure 3. The first and second harvests are indicated by sudden drops in height curves. In May the number of territories varied from 0.94 per hectare to 0.72 until the first harvest. Five days later the number had dropped to 0.5. It recovered shortly afterwards almost to its former level but fell close to zero in the middle of July. Although many skylarks were singing and recorded as holding territories on 24 June, it is probable that only a small proportion of pairs laid a replacement clutch, judging from our observations. Only 0.25 territories per hectare were recorded on 8 July in the silage field.

Figure 4 shows that the main ringing period in Svealand 1962-2001 is the whole month of June. The young are estimated to be about 6 days of age when ringed and the main breeding period counted from the first egg laid is thus normally approximately between 5 May and 5 June in central Sweden.

\section{Effect of silage harvest}

During the silage harvest careful observations of skylark behaviour were made. Systematic searches for nests were carried out 5, 6 and 9 June. The complete field notes from these occasions are attached (Appendix 2). No nests were found in the stubble between the lying grass strips. The lying grass cov-

Table 3. Breeding cycle for the skylark after Donald (2004).

Häckningscykel för sånglärka efter Donald (2004).

\begin{tabular}{|c|c|c|}
\hline $\begin{array}{l}\text { Activity } \\
\text { Aktivitet }\end{array}$ & $\begin{array}{l}\text { Time in days } \\
\text { Tid i dagar }\end{array}$ & $\begin{array}{l}\text { Comments } \\
\text { Kommentarer }\end{array}$ \\
\hline Restart after failure Tid att starta omläggning & ca 5 & Uncertain Osäker \\
\hline Nest building Bobyggnad & ca 5 & Uncertain Osäker \\
\hline Laying of eggs Äggläggning & $3-5$ & $\begin{array}{l}\text { Varies with the number } \\
\text { of eggs, } 1 \text { egg per day } \\
\text { Varierar med antal ägg, } \\
1 \text { ägg per dag }\end{array}$ \\
\hline Incubating Ruvning & $11-12$ & \\
\hline Feeding young in nest Matning av ungar $i$ bo & $8-9$ & \\
\hline Feeding young outside nest Matning av ungar utanför bo & $8-11$ & \\
\hline Sum & $40-47$ & \\
\hline
\end{tabular}


ered some $75 \%$ of the field area after cut (Photo 2 ). Many predators (mainly harriers, corvids and gulls) were also searching for living creatures in the field. Observations by field staff suggested that no nests survived the cut and the subsequent predator search. Confused behavior of adult skylarks was also observed (see Appendix 2). A pair of ortolan buntings showed signs of having had a nest in the silage field and this also appeared to have been destroyed by the harvest (the male changed his song behaviour after the grass harvest).

Also in 2014 another silage field of the same size as that at Sörby estate was cut, this year on 27 May. The observations on that occasion were similar to those in the main study year, 2015. The same species of predators were present and no surviving skylark nests were found. However, a nest with known approximate position before the cut was seen to be predated in the stubble by a crow Corvus corone.

\section{Search for nests}

Intensive feeding of young in the cereal fields was not observed by the staff until Midsummer but it had probably been going on for some time. The weather was very bad before Midsummer and prevented detailed observations. However, on 30 June and 1 July a search for nests was carried out in order to get blood samples from nestlings. We located approximate positions for six nests in spring seed, three at each farm. Most chicks by this time had left the nest and were being fed by the parents in the area surrounding the nest. Four pairs were observed to feed in this manner, whilst two nests still had young in the nest cup. These nests were visited. The nestlings were around eight to nine days old, and almost ready to leave the nest.

One replacement nest with skylarks feeding three young was found in the silage field on 9 July. The chicks were estimated to be around five days old. This indicates an incubation start date of 23 June, which agrees with a breeding cycle beginning directly after harvest on 9 June (see also Table 3 ). In the large silage field additional replacement nests were searched for but no more were located.

\section{Discussion}

\section{Skylark breeding period in central Sweden}

It is important to state that no systematic search for nests was made, except after the first harvest of the silage field. Therefore, we do not know the relationship between singing territories and nests or the exact timing of nesting in our study plots. Our previous experience of visiting nests in homogeneous fields has demonstrated a negative impact on breeding success; it is not possible to fully avoid a track in the crop, which may guide predators to the nest. Three ortolan and two skylark nests have probably been predated for this reason in recent years at Kvismaren.

The skylark breeding cycle is presented in Table 3 . The duration of the breeding cycle is at a minimum 40 days including restart after failure (after Donald 2004). It will take some days to restart the breeding, so this is an uncertain estimate. Also the amount of time spent on nest building is uncertain, but is estimated to another five days. The figures

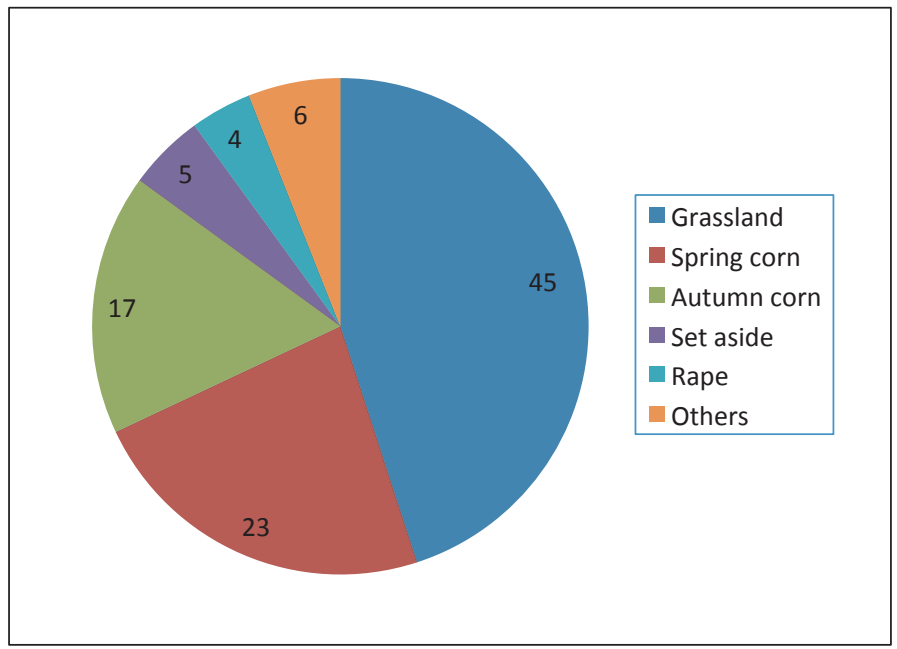

Figure 5. Use of arable land in Sweden 2014 in percent. Total area 2.6 million hetares. (Data from Jordbruksverket).

Akermarkens användning $i$ Sverige $i$ procent 2014. Grödorna är ordning vall, vårsäd, höstsäd, träda, raps och övrigt. Total area 2,6 miljoner hektar. 
for egg laying, incubation and feeding of young are more reliable, summing up to 30-37 days (after Donald 2004). The skylark breeding period is rather long (Figure 4) and probably influenced by the height of different crops and replacements due to predation and harvest failures. It is thus uncertain if the replacement nest we found on 9 July was successful. Time between harvests one and two was 43 days in 2015 , as the second cut was delayed by a week due to rainy weather. Normally the two successive cuts in late May and early July within some 35 days would totally wipe out the skylark production in the grassland fields of the Kvismaren valley. Furthermore, only a small proportion of the larks laid a replacement clutch. By the middle of July silence prevailed in the study area. A second brood is also unlikely in Sweden due to the time demand for moult (Ginn et al. 1983).

The significance of different types of farms and crop for the reproduction of skylarks at Kvismaren

We found no significant difference in skylark numbers between organic and conventional farming at Kvismaren. The average number of territories were similar at both farms, and in different types of crops.

The same density of skylarks as in Kvismaren (some 75 pairs per $\mathrm{km}^{2}$ ) was recorded in a Swedish study on an organic farm in Uppland (Berg \& Kvarnbäck 2011). Compared to other studies in Europe (compiled by Donald 2004) this occurrence is very high and may well be related to the very high proportion of spring seed in the Kvismaren valley. Only about $10-15 \%$ of the farmland at larger estates in this part of Närke is used as grassland (Markus Grenestam, Örebro County Administrative Board, pers. com.) and autumn seed is avoided in large areas due to potential for root damage.

Skylark males compete in spring for nesting territories within their home area. The birds are already at their breeding grounds in March. They are very faithful to the territory held the previous year (Delius 1965). Then they wait for around two months for adequate conditions to be able to start breeding; most importantly for vegetation which is high enough to hide the nest. As the farmers rotate the crops in a 3-5 year cycle, the larks may either wait for the vegetation to grow high enough, or move to adjacent fields. The males probably use both strategies. The start of the nesting period in a certain crop may then be fairly synchronized. The grassland is probably a favorable breeding habitat
(Kuiper et al. 2015). The even distribution in different crops (75-83 pairs $\mathrm{km}^{2}$ ) at Kvismaren can probably be explained by the lark's faithfulness to a particular area in combination with rotation of crops in the actual fields from year to year.

In Switzerland Jenny (1990) found in a limited area that intensive cutting of grass (every month) destroyed all nests, mirroring the results presented here. In areas largely comprised of grassland, such a farming technique may eliminate the entire skylark population. In the interior of northern Sweden the grassland share of the arable land nowadays is very high (some 90\%, Jordbruksverket 2014). In this part of the country the skylark decrease is most rapid (Green et al. 2016). The early harvest is probably the main reason why very low figures are reported in density comparisons and production of young when it comes to intensively used grassland all over Europe (Buckingham et al. 2015, Donald et al. 2002, Wakeham-Dawson \& Smith 2000, Poulsen 1993, Jenny 1990). In Kvismaren spring seed is fortunately dominant.

The number of territories in the autumn crops during the middle of May is as high as in the other types of crops, but possibly the skylarks breeding there are arrested by the fast growing crop. High vegetation is not optimal for searching of food (Donald 2004). However, at Kvismaren there is plenty of ground with lower vegetation around, in fields recently sown with spring seed or other late crops (potatoes, carrots, etc.). Therefore, it may be easy for the larks to find sufficient feeding areas at moderate distances if the nest is laid in autumn seed. The carrot field (Figure 1) is a good example of this. It was also utilized by many feeding larks from the surrounding fields of spring seed. A feeding distance of up to $150 \mathrm{~m}$ is normal for this species (Donald 1999) and probably it can be extended if necessary. Donald (2004) gives an example of a pair of skylarks nesting in autumn seed searching for food in a set aside area $500 \mathrm{~m}$ away from the nest.

In spring sown cereals the breeding cannot start until the vegetation is high enough to hide the nest. This year it happened at the beginning of June (Figure 4, see also Photo 1). Most of the fields in Kvismaren are sown with spring seed because of the risk for ice lift of the roots of small growing plants sown in the autumn. This means that the skylark population at Kvismaren is comparatively strong. What is the situation in other parts of the country? 
The significance of different grain for the reproduction of skylarks in Sweden

Figure 5 shows the proportions of different crops in Sweden in 2014. Hay, silage and other animal forage cover $45 \%$ (excluding semi-natural pastures) and cereals some $40 \%$ of the arable land area. The remaining part is mainly occupied by set aside areas and oil seed rape but also sugar beets, potatoes and leguminous plants. The cereal area is divided into autumn seed, some $17 \%$ (in 2013 only $10 \%$ ) and spring seed $23 \%$.

In this context it is also important to be aware that the agricultural area in Sweden has decreased since 1975 by around 400000 hectares $(13 \%)$. This also of course, has an impact on the number of skylarks present. The proportion of grassland has been fairly constant over the years (Wretenberg et al. 2006), but the cultivation technique has changed dramatically. Up to the 1980s and beginning of 1990s the harvest output was dry hay. To harvest that kind of material, the straws needed cellulose content for the handling, which generally prevented cut before the middle of June. In the 1990s the harvest gradually changed from hay to soggy silage and earlier cuts, in which better nutrient content were possible to achieve. In Örebro county for example the dry hay share was $86 \%$ and the silage $13 \%$ in 1992 (SCB 1993). Today the proportion of silage is over $90 \%$ and the intensity in cultivation of grassland has increased, generating successively earlier and more harvest rounds in a season.

Monitoring shows that the skylark has decreased in Sweden in recent decades (Wretenberg et al. 2007, Green et al. 2016). However, different methods for collecting data show different results. During the period 1975-2014 a severe decrease of $72 \%$ was calculated based on observers' free-choice of sample sites. In 1998 a more reliable system was introduced, namely fixed sites evenly covering the whole country (Green et al. 2016). During the period 1998-2014 the new scheme estimated a decline of $21 \%$ compared to $45 \%$ during the same period for the free-choice scheme. The skylark has obviously decreased in number in Sweden but it is uncertain how big that decrease is.

In total some 800000 skylark pairs breed in Sweden today (actually 2008, Ottosson et al. 2012). Out of these 680000 breed on cultivated farmland, and the remaining 120000 pairs nest on natural grassland, mainly on the islands of Öland and Gotland. Our study in Kvismaren indicates that the change to grass silage cropping, besides the decrease in farmland area, may be an important and overlooked driver of population declines of skylarks and other field nesting species. Skylarks breeding in cereal crops are normally not seriously affected by farming methods. Only in areas where autumn seed strongly dominates may there be a risk for lack of feeding habitats because of the high vegetation. Autumn seed areas are mainly situated in the counties of Skåne, Västra Götaland, Östergötland and Uppland where the autumn crop covers one quarter of the farmland area. Despite that, these counties keep two thirds $(66 \%)$ of the skylark population on farmland in Sweden (Ottosson et al. 2012).

In 2012 SOF BirdLife Sverige introduced the program Rädda Sånglärkan (http://www.raddasanglarkan.se/; transl.: Save the Skylark) for creating unsown patches in autumn-sown cereal fields (Skylark plots; 1-2 per hectare, 16-20 m2/plot). These have been shown to improve the quality of breeding habitat by increasing food availability in dense vegetation in England (Morris et al. 2004, RSPB leaflet), where the autumn or winter seed is totally dominant. Studies in Sweden have not been able to verify such benefit (Berg \& Kvarnbäck 2011, Hiron et al. 2012). It is possible that the main reason for the skylark setback in Sweden is not the height and density of the autumn seed but, alongside the shrinking total farming area, the successively lower reproduction rate in grasslands because of the increasing intensity in harvesting over recent decades. A more successful way to support the larks in autumn seed areas would probably be to depart homogenous areas of autumn seed and breed other crops in between (Chamberlain et.al. 1999). Rotation of crop is a natural element in the farmer's planning.

\section{Is it possible to improve the skylark outcome in grassland fields?}

The repeated harvest of silage several times per season is today a standardised method to optimise quality and volume of the yield from grassland. This optimisation has been refined during many decades. A delay of the first, and for the skylark, the most disastrous harvest would affect the quality of the silage the most; the early harvested high quality grass is required to get maximal milk production and thus a good economic return for the farmers. There is obviously no simple solution to the time schedule problem. A three to four weeks delay (until after Midsummer) of the harvest would spare many broods (Figure 4) but the quality of the silage would in general decrease too much (Jordbruksverket 2014). 
What can we do to address this? We know that the skylarks avoid parts of the fields bordering tall trees. Oelke (1968) estimated a distance from about 100 to $200 \mathrm{~m}$ dependent of the height of the adjacent forest. These areas of the fields are usually possible to harvest on time without causing any harm to the larks. Also smaller fields, less than around 10 hectares, surrounded by trees are possible to harvest as they are not utilised by the larks (Piha et al. 2003). However, in the few ortolan bunting breeding areas these are not good solutions as the species often nests close to smaller wooded islets within the fields.

Areas in the central part of the field might also be left for the skylark 3-4 further weeks, and this food could be reserved for recruits to the milk stock and cows not producing milk for the moment. Also sucker cows demand less nutritious food (Nilla Nilsdotter-Linde, pers. com.). With such a strategy a system for compensation to farmers for delaying harvest in order to protect the skylark nests (and other ground breeding birds such as partridge, pheasant, corncrake, quail, curlew, lapwing, corn bunting, etc.) is probably necessary to introduce. Also Montagu's harrier nesting on farmland on Öland suffers from the early cut (Rodebrand 2016). To leave set-asides more or less covered with vegetation during the breeding period is another good option.

A new possibility is available in some primary agricultural areas because grass is a good basis for producing biogas. Instead of producing silage for cows, the grass may be transported to a plant and fermented for biogas production. There are such plants in Västerås and Örebro. In a case study Dahlgren (2013) calculated on a possible expansion of biogas until 2030 (medium case) to make use of 5\% of the agricultural area in Sweden. The possibility of expansion is however uncertain and very much dependent on oil price and on political decisions. The advantage with gas production in this context would be that it is possible to harvest the grass somewhat later. How much later is today unknown and must be studied.

Further studies focusing on the skylark nest distribution in different fields in Sweden are desirable. With such local knowledge, development of an adapted harvest of the grasslands to decrease losses of skylark nests and other animals dwelling in the grass may be possible.

\section{Conclusions}

A survey of skylarks at Kvismaren, central Sweden, in 2015 showed that the abundance was 75-83 pairs per $\mathrm{km}^{2}$. No significant differences due to crop and cultivation system in the study area of 200 hectares could be identified. Both in 2014 and 2015 the first harvest of grass for silage likely destroyed all nests. A few pairs laid a replacement clutch but there is normally not time enough to allow these young to fledge before the next cut. There are no such major threats in the grain fields. The best nesting habitat at Kvismaren is probably the large proportion of spring seed where the vegetation is shorter than in the autumn seed during the breeding period of the skylarks. Autumn triticale also grows higher than the spring cereals crops wheat and oats.

The program for creating skylark plots in autumn grain to improve the breeding habitats for skylarks in Sweden ought to be evaluated. An option would be to use resources earmarked for skylarks to delay part of the harvest for silage in certain areas or get a better mixture between fields with autumn seed and other crops. Further studies focusing on ways and means for this are needed.

\section{Acknowledgements}

We thank Elisabeth Kopp for excellent survey work and Sönke Eggers for comments on an early version of the manuscript. Alvins fond has financially supported the study. Kvismare Bird Observatory lodged the field workers for two and a half months.

This is contribution No. 176 from Kvismare Bird Observatory.

\section{References}

ArtDatabanken 2015. Rödlistade arter i Sverige 2015. ArtDatabanken SLU, Uppsala.

Berg, Å. \& Kvarnbäck, O. 2011. Density and reproductive success of Skylarks Alauda arvensis on organic farms - an experiment with unsown Skylark plots on autumn sawn cereals. Ornis Svecia 21: 3-10.

Birdlife International. http://www.birdlife.org/datazone/speciesfactsheet.php?id=8177

Buckingham, D.L., Giovannini, P. \& Peach, W.J. 2015. Manipulating grass silage management to boost reproductive output of a ground-nesting farmland bird. Agriculture, Ecosystems and Environment 208: 21-28.

Chamberlain, D.E., Wilson, A.M., Browne, S.J. \& Vickery, J.A. 1990. Effects of habitat type and management on the abundance of skylarks in the breeding season. Journal of Applied Ecology 36: 856-870.

Dahlgren, S. 2013. Realiserbar biogaspotential $i$ Sverige 2030 genom rötning och förgasning. Rapport daterad 2013-04-10 från WSP Sverige AB. 102 sid. 
Delius, J.D. 1965. A population study of skylarks Alauda arvevsis. Ibis 107: 466-492.

Donald, P. F. 1999. The Ecology and Conservation of Skylarks Alauda arvensis on Lowland Farmland. Unpublished DPhil. Thesis. University of Oxford.

Donald, P.F., Evans, A.D., Muirhead, L.B., Buckingham, D.L., Kirby, W.B. \& Schmitt, S.I.A. 2002. Survival rates, causes of failure and productivity of Skylark Alauda arvensis nests on lowland farmland. Ibis 144: 652-664.

Donald, P.F. 2004. The Skylark. London.

Ginn, H.B. \& Melville, D.S. 1983. Moult in Birds. BTO guide 19 , Tring.

Green, M., Haas, F. \& Lindström, Å. 2016. Övervakning av fåglarnas populationsutveckling, årsrapport för 2015. Biologiska institutionen, Lunds universitet.

Grüebler, M.U., Schuler, H., Horch, P. \& Spaar, R. 2012. The effectiveness of conservation measures to enhance nest survival in a meadow bird suffering from anthropogenic nest loss. Biological Conservation 146: 197-203.

Hiron, M., Berg, Å. \& Pärt, T. 2012. Do skylarks prefer autumn sown cereals? Effects of agricultural land use, region and time in the breeding season on density. Agriculture, Ecosystems and Environment 150: 82-90.

Jenny, M. 1990. Populationsdynamik der Feldlerche Aluanda arvensis in einer intensiv genutzten Agrarlandschaft des schweizerischen Mittelandes. Ornithologische Beobachter 87: 153-163.

Jordbruksverket 2014. Bra vallfoder till mjölkkor. Jordbruksinformation 10-2014. Jönköping.

Jordbruksverket. Jordbruket i siffror: https://jordbruketisiffror.wordpress.com/2014/05/15/sahar-anvands-akermarken-i-ar/

Kuiper, M.W., Ottens, H.J., van Ruijven, J., Koks, B.J., de Snoo, G.R. \& Berendse, F. 2015. Effects of breeding habitat and field margins on the reproductive performance of Skylarks (Alauda arvensis) on intensive farmland. Journal of Ornithology 156: 557-568.

Morris, A.J., Holland, J.M., Smith, B. \& Jones, N.E. 2004. Sustainable Arable Farming for an Improved Environment (SAFFIE): managing winter wheat sward structure for Skylarks Alauda arvensis. 0 146: 155-162.

Morris, A., J. \& Golroy, J.J. 2008. Close to the edge: predation risks for two declining Farmland passerines. Ibis 150: (Suppl. 1), 168-177

Oelke, H. 1968. Wo beginnt bzw. wo endet der Biotop der Feldlerche? Journal für Ornithologie 109: 25-26.

Ottvall, R., Edenius, L., Elmberg, J., Engström, H., Green, M., Holmqvist, N., Lindström, Å., Pärt, T. \& Tjernberg, M. 2009. Population trends for Swedish breeding birds. Ornis Svecica 19: 117-192.

Ottosson, U., Ottvall, R., Elmberg, J., Green, M., Gustafsson, R., Haas, R., Holmqvist, N., Lindström, A., Nilsson, I., Svensson, M., Svensson, S. \& Tjernberg, M. 2012. Fåglarna i Sverige - antal och förekomst. SOF, Halmstad.

Poulsen, J.G. 1993. Comparative ecology of skylarks (Alauda arvensis) on arable land. M. Sc. thesis, University of Aarhus.

Piha, M., Pakkala, T \& Tiainen, J. 2003. Habitat preferences of the Skylark Alauda arvensis in southern Finland. Ornis Fennica 80(3): 97-110.

Praus, L. \& Weidinger. K. 2010. Predators and nest success of Sky Larks Alauda arvensis in large arable fields in the Czech Republic. Bird Study 57: 525-530
RSPB leaflet: http://www.rspb.org.uk/images/skylarkplot_ tcm9-132769.pdf

Rodebrand, S. 2016. Dåligt boval hot mot ängshöken. Vår Fågelvärld 75(1): 22-26.

Sondell, J., Brookes, C. \& Persson, M. 2011. Ortolan Bunting Emberiza hortulana at Kvismaren, central Sweden - breeding studies and suggested management. Ornis Svecia 21: 167-174.

Statistiska Centralbyrån (SCB) 1993. Växtodlingen 1992. Uppgifter från de objektiva skördeuppskattningarna. Stencil, beställningsnummer J 12 SM 9302.

Wakeham-Dawson, A. \& Smith, K.W. 2000. Birds and lowland grassland management practices in the UK: an overview. Ecology and Conservation of Lowland Farmland Birds. Spring Conference of the British Ornithologists' Union, 27-28 March 1999, Southampton, UK, 77-88.

Vickery, J.A., Tallowin, J.R., Feber, R.E., Asteraki, E.J., Atkinson, E.J., Fuller, R.J. \& Brown, V.K. 2001. The management of lowland neutral grasslands in Britain: effects of agricultural practices on birds and their food resources. Journal of Applied Ecology 38(3): 647-664.

Wretenberg, J., Lindström, A., Svensson, S., Thierfelder, T. \& Pärt, T. 2006. Population trends of farmland birds in Sweden and England: similar trends but different patterns of agricultural intensification. Journal of Applied Ecology 43: 1110-1120.

Wretenberg, J., Lindström, Å., Svensson, S., \& Pärt, T. 2007. Linking agricultural policies to population trends of Swedish farmland birds in different agricultural regions. Journal of Applied Ecology 44: 933-941.

\section{Sammanfattning}

År 2014 genomfördes studier av ortolansparv i Kvismaren och i samband med detta togs blodprov på bl.a. lärkungar för att se om växtskyddsmedel anrikades i åkerhäckande tättingar. Därvid upptäcktes att vallodlingarna skördades långt innan ungarna i lärkbona var utflugna. Alla lärkbon förstördes. Därför genomfördes under 2015 en inventering av sånglärka med syfte att undersöka hur odlingsmetoderna i jordbruket påverkade sånglärkans revirtäthet i olika grödor och om det var någon skillnad på ekologisk och konventionell odling. Odling av vall, höstsäd och vårsäd ingick i studien.

\section{Resultat}

Totalt inventerades ungefär 200 hektar jordbruksmark på två stora gårdar i Kvismardalen; Sörby och Bärsta. Fördelning på grödor och antal provytor framgår av Tabell 1. Studieområdet med provytor redovisas i Figur1. Alla insamlade studiedata redovisas i Appendix 1.

Vegetationens utveckling har stor betydelse för när lärkan kan börja häcka. Stråhöjden i olika grödor redovisas vid olika tidpunkter i Figur 2. I Figur 3 presenteras revir av sånglärka i olika grödor på 
Sörby och Bärsta i relation till grödans höjd vid olika tidpunkter under våren-försommaren. Antalet revir är lägre där vegetationen är högre. Antalet revir är ungefär detsamma vid samma vegetationshöjd på de två gårdarna. Den lägre tätheten av lärkrevir i vårsäd på Sörby kan kanske förklaras av närheten till träddungar (Figur 1) eller till vallodlingen, som erbjuder optimala förutsättningar. Vallar saknas på Bärsta.

Skörd 1 och 2 i vallodling på Sörby indikeras av en momentan nedgång $i$ vegetationens höjd. På våren registrerades mellan 0,92 och 0,72 revir per hektar. Antalet sjönk till 0,5 efter första skörd. Det ökade sedan igen men föll till nära noll i mitten av juli.

Trots noggrant sök efter slåttern hittades varken skadade eller hela lärkbon (Appendix 2). Den första slåttern förstörde uppenbarligen alla bon eftersom fältet antingen var penetrerat av hjulspår eller täckt av hösträngar på ca $75 \%$ av arealen. Den kvarvarande stubben patrullerades av kråkor och kärrhökar och flera andra predatorer. År 2014 bevittnades även hur ett frilagt lärkbo plundrades på sina ungar av kråka. Ett par ortolansparvar fick sannolikt också sitt bo förstört av slåttern.

Sök efter lärkbon för blodprovtagning skedde inte förrän i månadsskiftet juni-juli. Vädret veckorna innan hade varit mycket regnigt och kallt. Fyra bon där ungarna matades efter att ha lämnat boet noterade i månadsskiftet och två där ungarna fortfarande var i boet, 8-9 dagar gamla, alla i vårsäd jämnt fördelade på Bärsta och Sörby. I vallodlingen hittades den 9 juli en omlagd kull med lärkungar som var ca 5 dagar gamla. Det är osäkert om denna kull hann bli flygg innan nästa skörd, som något försenad på grund av regnigt väder, ägde rum den 22 juli, se sånglärkans häckningscykel i Tabell 3. En tredje skörd togs 23 september.

\section{Diskussion}

I Figur 4 redovisas 137 kullar av sånglärka märkta i mellersta Sverige 1962-2001, data från Ringmärkningscentralen, tillsammans med de slumpvis funna kullar som märkts i Kvismaren 2014 och 2015. Om ungarna vid märkningen är ca 6 dagar kan man beräkna att den huvudsakliga häckningstiden startar i perioden 5 maj till 5 juni i mellersta Sverige.

Häckningsperioden är relativt lång och styrs av höjden på olika grödor och av de omläggningar som sker på grund av predation och skador på bona vid skörd. Med gällande skördeintervaller får sånglärkorna inte alls några ungar på vingarna i vallodlingarna. Dessutom lägger få par om, åtminstone var det så i Kvismaren 2015. Tidsåtgången för ruggning efter häckningen begränsar också föräldrarnas möjligheter till omläggning.

Inventeringsresultatet i Kvismaren visar på ungefär samma täthet, 75-83 revir per kvadratkilometer, oberoende av gröda. Detta är ett relativt högt värde jämfört med andra studieresultat i Europa. Att sånglärkan har en så stark stam i Kvismaren beror troligen på att andelen vallodling är liten.

Sånglärkan är starkt hemortstrogen. Den anländer till hemmaåkern i mars och väntar sedan på att vegetationen ska bli så hög att den kan börja häcka. Jordbruket tillämpar en växtföljd som gör att lärkan måste häcka i olika grödor olika år. I höstsäd och vallodling kan den starta tidigare än i vårsäd. Om vegetationen blir för tät för födosök finns andra grödor i omgivningen att besöka (Figur 1).

Figur 5 visar fördelningen av olika grödor i Sverige år 2014. Vallodling (exklusive naturbeten) utgör $45 \%$ av åkerarealen. Höstsäd utgjorde $17 \%$ (en relativt hög siffra, år 2013 var andelen bara 10\%) och vårsäd $23 \%$. När man diskuterar arealer i förhållande till sånglärkans förekomst är det också viktigt att veta att 400000 hektar jordbruksmark har lagts ner sedan 1975. Det innebar 13\% av arealen, som nu är ca 2,6 miljoner hektar. Andelen vallodling har varit ungefär lika genom åren men skördetekniken har ändrats dramatiskt från torrt hö till fuktigt ensilage. Höskörden skedde i regel omkring midsommar medan det första ensilaget tas redan $\mathrm{i}$ slutet av maj när lärkan har nykläckta ungar i bona.

Inventeringar har visat att sånglärkan minskat i antal i Sverige under senare decennier. Under perioden 1975-2014 var minskningen hela 72\% enligt sommarpunktrutterna i Svensk fågeltaxering. De objektivt utlagda standardrutterna visar en nedgång på 21\% under åren 1998-2014. Motsvarande värde för sommarpunktrutterna var $48 \%$. Sånglärkan har uppenbart minskat men hur mycket och orsakerna kan diskuteras. Dels har den minskade åkerarealen haft betydelse men i övrigt är det troligt att det successivt allt effektivare utnyttjandet av vallarna med flera och tidigare skördar är den största orsaken till minskningen. De områden som har mest höstsäd har också den största populationen sånglärka. Skåne, Västra Götaland, Östergötland och Uppland hyser $66 \%$ av populationen sånglärka på åkermark i Sverige.

År 2012 introducerade SOF-Birdlife Sverige programmet Rädda Sånglärkan med syfte att skapa lärkrutor (1-2 stycken per hektar, 16-20 m²) för att öka sånglärkornas möjligheter att skaffa föda. Idén kom från England där höst- eller vintersådd är helt dominerande. Om huvudorsaken till sånglär- 
kans tillbakagång, vid sidan av arealminskningen, är den dåliga reproduktionen på vallarna, kan nyttan av denna satsning ifrågasättas. En satsning på 2400 lärkrutor per år för att gynna en lärkpopulation på 680000 par på åkermark kan i bästa fall ge en marginell förbättring. Från England rapporteras dessutom att lärkan kan flyga upp till $500 \mathrm{~m}$ för att födosöka på ett omtyckt näringsställe, även om så stort avstånd är undantag.

Det är uppenbart att man inte kan senarelägga skörden av vallarna av naturskyddsskäl utan att det får konsekvenser för lantbrukarnas ekonomi. Det finns därför ingen enkel lösning för att skydda lärkbona från förstörelse. Lärkan häckar dock inte på mindre fält $(<10$ hektar) och inte närmare åkerkanter med höga träd än 100-200 m. På sådana delar av arealen kan man skörda utan problem för sånglärkan. Vissa typer av boskap behöver heller inte det mest fullvärdiga fodret vilket betyder att vissa lärktäta fält kanske kan sparas ungefär de 3-4 veckor till efter midsommar som behövs för att ungarna ska bli flygga före skörd. Att lämna delvis ogrästäckta trädor är ett annat bra alternativ.
Ytterligare studier är önskvärda på åkermarker i Sverige. Med lokal kunskap kan man eventuellt utveckla nya skördemodeller med syfte att minska skadan så mycket som möjligt. I sammanhanget bör kanske också ett ersättningssystem till lantbrukarna utvecklas.

\section{Slutsatser}

Sånglärkan har en stark stam i Kvismaren, det finns 75-83 revir per kvadratkilometer oberoende av gröda och typ av gård. Både 2014 och 2015 förstördes sannolikt alla bon i vallodlingar inom studieområdet vid den första skörden. Eventuella omläggningar förstördes med största sannolikhet också i samband med efterföljande skördar. Det finns inga sådana hot på sädesfälten. Den nuvarande satsningen på lärkrutor ter sig mot denna bakgrund tveksam, och projektupplägget bör därför utvärderas. Kanske kan medel avsedda för sånglärkan användas på ett bättre sätt genom att lämna ekonomiska bidrag till senareläggning av vallskörden på vissa fält eller delar av fält. 
Appendix 1

Data from all survey plots and visits in 2015.

Data för alla provytor och besök 2015.

\begin{tabular}{|c|c|c|c|c|c|c|}
\hline $\begin{array}{l}\text { Plot } \\
\text { no. } \\
\text { Yta } \\
n r\end{array}$ & $\begin{array}{r}\text { Visit } \\
\text { no. } \\
\text { Besök } \\
n r\end{array}$ & $\begin{array}{l}\text { Date } \\
\text { Datum }\end{array}$ & $\begin{array}{r}\text { Start } \\
\text { time } \\
\text { Start- } \\
\text { tid }\end{array}$ & $\begin{array}{c}\text { Singing } \\
\text { males } \\
\text { Sjungande } \\
\text { hanar }\end{array}$ & $\begin{array}{l}\text { Height of } \\
\text { crop (cm) } \\
\text { Grödans } \\
\text { höjd (cm) }\end{array}$ & $\begin{array}{l}\text { Surv- } \\
\text { eyor } \\
\text { Inven- } \\
\text { terare }\end{array}$ \\
\hline \multicolumn{7}{|c|}{ Sörby, autum crop vårsäd } \\
\hline 1 & 1 & $12-5-15$ & 0621 & 3.0 & 30 & JMY \\
\hline 1 & 2 & $22-5-15$ & 0812 & 2.5 & 30 & EKP \\
\hline 1 & 3 & $6-6-15$ & 0934 & 1.5 & 62 & EKP \\
\hline 1 & 4 & $24-6-15$ & 0647 & 1.5 & 100 & JMY \\
\hline 1 & 5 & $7-7-15$ & 0801 & 0.5 & 120 & JMY \\
\hline 2 & 3 & $12-5-15$ & 0642 & 4.0 & 30 & DWE \\
\hline 2 & 4 & $22-5-15$ & 0812 & 2.0 & 30 & JMY \\
\hline 2 & 5 & $10-6-15$ & 0909 & 1.0 & 65 & EKP \\
\hline 2 & 6 & $24-6-15$ & 0710 & 0.5 & 120 & JMY \\
\hline 2 & 7 & $4-7-15$ & 0742 & 0.0 & 110 & JMY \\
\hline 3 & 1 & $12-5-15$ & 0622 & 1.5 & 30 & DWE \\
\hline 3 & 2 & $22-5-15$ & 0850 & 3.5 & 30 & EKP \\
\hline 3 & 3 & $9-6-15$ & 0934 & 1.5 & 62 & EKP \\
\hline 3 & 4 & $24-6-15$ & 0623 & 1.5 & 90 & JMY \\
\hline 3 & 5 & $4-7-15$ & 0721 & 1.0 & 100 & JMY \\
\hline
\end{tabular}

\begin{tabular}{|c|c|c|c|c|c|c|}
\hline $\begin{array}{l}\text { Plot } \\
\text { no. } \\
Y t a \\
n r\end{array}$ & $\begin{array}{r}\text { Visit } \\
\text { no. } \\
\text { Besök } \\
n r\end{array}$ & Datum & $\begin{array}{r}\text { Start } \\
\text { time } \\
\text { Start- } \\
\text { tid }\end{array}$ & $\begin{array}{c}\text { Singing } \\
\text { males } \\
\text { Sjungande } \\
\text { hanar }\end{array}$ & $\begin{array}{l}\text { Height of } \\
\text { crop }(\mathrm{cm}) \\
\text { Grödans } \\
\text { höjd }(\mathrm{cm})\end{array}$ & $\begin{array}{l}\text { Surv- } \\
\text { eyor } \\
\text { Inven- } \\
\text { terare }\end{array}$ \\
\hline 7 & 6 & $7-7-15$ & 0812 & 0.5 & 35 & JMY \\
\hline 7 & 7 & $11-7-15$ & 0755 & 0.0 & 27 & JMY \\
\hline 8 & 1 & $12-5-15$ & 0726 & 2.5 & no data & JMY \\
\hline 8 & 2 & $22-5-15$ & 0726 & 2.0 & 15 & JMY \\
\hline 8 & 3 & $31-5-15$ & 0809 & 5.0 & 25 & EKP \\
\hline 8 & 4 & $14-6-15$ & 0837 & 3.5 & 15 & EKP \\
\hline 8 & 5 & $24-6-15$ & 0825 & 2.5 & 25 & JMY \\
\hline 8 & 6 & $7-7-15$ & 0751 & 2.0 & 35 & JMY \\
\hline 8 & 7 & $11-7-15$ & 0734 & 0.0 & 30 & JMY \\
\hline 9 & 1 & $12-5-15$ & 0748 & 5.0 & no data & JMY \\
\hline 9 & 2 & $22-5-15$ & 0705 & 2.0 & 30 & EKP \\
\hline 9 & 3 & $31-5-15$ & 0747 & 2.0 & 30 & EKP \\
\hline 9 & 4 & $14-6-15$ & 0812 & 1.5 & 15 & EKP \\
\hline 9 & 5 & $24-6-15$ & 0804 & 0.5 & 20 & JMY \\
\hline 9 & 6 & $7-7-15$ & 0731 & 0.0 & 30 & JMY \\
\hline 9 & 7 & $11-7-15$ & 0714 & 0.0 & 30 & JMY \\
\hline
\end{tabular}

\section{Sörby, hay $h \ddot{o}$}

\begin{tabular}{rrccrrl}
4 & 3 & $12-5-15$ & 0700 & 2.5 & no data & DWE \\
4 & 4 & $22-5-15$ & 0832 & 3.0 & 32 & EKP \\
4 & 5 & $30-5-15$ & 0800 & 2.0 & 40 & JMY \\
4 & 6 & $14-6-15$ & 0822 & 1.0 & 13 & MPN \\
4 & 7 & $24-6-15$ & 0815 & 3.5 & 20 & MPN \\
4 & 8 & $7-7-15$ & 0820 & 1.0 & 40 & MPN \\
4 & 9 & $11-7-15$ & 0730 & 1.0 & 50 & MPN \\
\hline 5 & 1 & $12-5-15$ & 0641 & 1.0 & $?$ & JMY \\
5 & 2 & $22-5-15$ & 0753 & 0.0 & 30 & JMY \\
5 & 3 & $30-5-15$ & 1042 & 1.0 & 40 & JMY \\
5 & 4 & $14-6-15$ & 0905 & 0.0 & 13 & MPN \\
5 & 5 & $24-6-15$ & 0855 & 2.5 & 20 & MPN \\
5 & 6 & $7-7-15$ & 0740 & 0.0 & 40 & MPN \\
5 & 7 & $11-7-15$ & 0817 & 0.5 & 50 & MPN \\
\hline 6 & 1 & $12-5-12$ & 0700 & 2.0 & no data & JMY \\
6 & 2 & $22-5-15$ & 0759 & 3.5 & 30 & EKP \\
6 & 3 & $30-5-15$ & 0820 & 2.0 & 38 & JMY \\
6 & 4 & $14-6-15$ & 0845 & 2.0 & 13 & MPN \\
6 & 5 & $24-6-15$ & 0835 & 2.0 & 20 & MPN \\
6 & 6 & $7-7-15$ & 0800 & 1.0 & 40 & MPN \\
6 & 7 & $7-11-15$ & 0755 & 0.0 & 50 & MPN \\
\hline 7 & 1 & $12-5-15$ & 0723 & 4.0 & no data & DWE \\
7 & 2 & $22-5-15$ & 0730 & 2.5 & 30 & EKP \\
7 & 3 & $31-5-15$ & 0830 & 1.5 & 33 & EKP \\
7 & 4 & $14-6-15$ & 0855 & 1.0 & 15 & EKP \\
7 & 5 & $24-6-15$ & 0846 & 1.5 & 25 & JMY \\
\hline & & & & & &
\end{tabular}

\section{Sörby, spring crop vårsäd}

\begin{tabular}{rrcccrl}
10 & 1 & $22-5-15$ & 0635 & 0.0 & 10 & EKP \\
10 & 2 & $30-5-15$ & 1104 & 0.0 & 12 & JMY \\
10 & 3 & $14-6-15$ & 0815 & 1.0 & 30 & JMY \\
10 & 4 & $25-6-15$ & 0605 & 0.5 & 40 & JMY \\
10 & 5 & $7-4-15$ & 0836 & 0.0 & 65 & JMY \\
\hline 11 & 1 & $22-5-15$ & 0644 & 0.0 & 0 & JMY \\
11 & 2 & $31-5-15$ & 0657 & 1.0 & 8 & JMY \\
11 & 3 & $14-6-15$ & 0835 & 0.0 & 30 & JMY \\
11 & 4 & $25-6-15$ & 0625 & 1.0 & 45 & JMY \\
11 & 5 & $4-7-15$ & 0857 & 1.0 & 75 & JMY \\
\hline 12 & 1 & $22-5-15$ & 0703 & 0.0 & 8 & JMY \\
12 & 2 & $31-5-15$ & 0713 & 0.5 & 10 & EKP \\
12 & 3 & $14-6-15$ & 0855 & 1.5 & 30 & JMY \\
12 & 4 & $25-6-15$ & 0645 & 1.5 & 45 & JMY \\
12 & 5 & $4-7-15$ & 0918 & 0.5 & 65 & JMY \\
\hline Bärsta, autum crop & höstsäd & & & \\
13 & 1 & $15-5-15$ & 0732 & 1.0 & 10 & JMY \\
13 & 2 & $24-5-15$ & 0750 & 0.5 & 45 & EKP \\
13 & 3 & $10-6-15$ & 0848 & 1.0 & 80 & JMY \\
13 & 4 & $24-6-15$ & 0630 & 0.5 & 125 & MPN \\
13 & 5 & $5-7-15$ & 0713 & 0.0 & 125 & JMY \\
\hline 14 & 1 & $15-5-15$ & 0736 & 2.0 & 10 & EKP \\
14 & 2 & $24-5-15$ & 0755 & 3.0 & 45 & MPN \\
14 & 3 & $9-6-15$ & 0939 & 1.0 & 70 & JMY \\
14 & 4 & $24-6-15$ & 0655 & 0.0 & 125 & MPN \\
14 & 5 & $5-7-15$ & 0653 & 0.0 & 125 & JMY \\
\hline & & & & & &
\end{tabular}




\begin{tabular}{|c|c|c|c|c|c|c|}
\hline $\begin{array}{l}\text { Plot } \\
\text { no. } \\
\text { Yta } \\
n r\end{array}$ & $\begin{array}{r}\text { Visit } \\
\text { no. } \\
\text { Besök } \\
n r\end{array}$ & $\begin{array}{l}\text { Date } \\
\text { Datum }\end{array}$ & $\begin{array}{r}\text { Start } \\
\text { time } \\
\text { Start- } \\
\text { tid }\end{array}$ & $\begin{array}{c}\text { Singing } \\
\text { males } \\
\text { Sjungande } \\
\text { hanar }\end{array}$ & $\begin{array}{l}\text { Height of } \\
\text { crop }(\mathrm{cm}) \\
\text { Grödans } \\
\text { höjd (cm) }\end{array}$ & $\begin{array}{l}\text { Surv- } \\
\text { eyor } \\
\text { Inven- } \\
\text { terare }\end{array}$ \\
\hline 15 & 1 & $15-5-15$ & 0736 & 3.0 & 10 & MPN \\
\hline 15 & 2 & $24-5-15$ & 0752 & 2.5 & 35 & JMY \\
\hline 15 & 3 & $9-6-15$ & 0959 & 1.0 & 70 & JMY \\
\hline 15 & 4 & $24-6-15$ & 0717 & 1.0 & 125 & MPN \\
\hline 15 & 5 & $5-7-15$ & 0635 & 0.5 & 125 & JMY \\
\hline 16 & 1 & $24-5-15$ & 0820 & 4.0 & no data & MPN \\
\hline 16 & 2 & $31-5-15$ & 0806 & 2.5 & no data & JMY \\
\hline 16 & 3 & $15-6-15$ & 0645 & 3.0 & 37 & EKP \\
\hline 16 & 4 & $26-6-15$ & 0840 & 2.5 & 50 & MPN \\
\hline 16 & 5 & $5-7-15$ & 0713 & 1.0 & 65 & JMY \\
\hline 17 & 1 & $24-5-15$ & 0825 & 4.0 & 15 & JMY \\
\hline 17 & 2 & $31-5-15$ & 0726 & 1.5 & 15 & JMY \\
\hline 17 & 3 & $15-6-15$ & 0650 & 2.5 & 37 & JMY \\
\hline 17 & 4 & $26-6-15$ & 0805 & 2.0 & 50 & MPN \\
\hline 17 & 5 & $5-7-15$ & 0759 & 1.0 & 65 & JMY \\
\hline 18 & 1 & $24-5-15$ & 0825 & 4.5 & 15 & EKP \\
\hline 18 & 2 & $31-5-15$ & 0744 & 2.0 & 15 & JMY \\
\hline 18 & 3 & $15-6-15$ & 0650 & 3.0 & 37 & MPN \\
\hline 18 & 4 & $26-6-15$ & 0750 & 3.0 & 50 & MPN \\
\hline 18 & 5 & $5-7-15$ & 0817 & 2.0 & 65 & JMY \\
\hline 19 & 1 & $23-5-15$ & 0755 & 2.0 & 10 & JMY \\
\hline 19 & 2 & $30-5-15$ & 0955 & 2.5 & 12 & EKP \\
\hline 19 & 3 & $14-6-15$ & 0939 & 3.0 & 28 & JMY \\
\hline
\end{tabular}

\begin{tabular}{|c|c|c|c|c|c|c|}
\hline $\begin{array}{l}\text { Plot } \\
\text { no. } \\
Y t a \\
n r\end{array}$ & $\begin{array}{r}\text { Visit } \\
\text { no. } \\
\text { Besök } \\
n r\end{array}$ & $\begin{array}{c}\text { Date } \\
\text { Datum }\end{array}$ & $\begin{array}{r}\text { Start } \\
\text { time } \\
\text { Start- } \\
\text { tid }\end{array}$ & $\begin{array}{c}\text { Singing } \\
\text { males } \\
\text { Sjungande } \\
\text { hanar }\end{array}$ & $\begin{array}{l}\text { Height of } \\
\text { crop }(\mathrm{cm}) \\
\text { Grödans } \\
\text { höjd }(\mathrm{cm})\end{array}$ & $\begin{array}{l}\text { Surv- } \\
\text { eyor } \\
\text { Inven- } \\
\text { terare }\end{array}$ \\
\hline 19 & 4 & $25-6-15$ & 0804 & 1.5 & 40 & JMY \\
\hline 19 & 5 & $4-7-15$ & 0605 & 1.0 & 60 & JMY \\
\hline \multicolumn{7}{|c|}{ Sörby, spring crop vårsäd } \\
\hline 20 & 1 & $23-5-15$ & 0813 & 2.5 & 10 & JMY \\
\hline 20 & 2 & $30-5-15$ & 1015 & 3.5 & 12 & EKP \\
\hline 20 & 3 & $14-6-15$ & 0942 & 4.5 & 23 & EKP \\
\hline 20 & 4 & $25-6-15$ & 0722 & 0.0 & 40 & JMY \\
\hline 20 & 5 & $4-7-15$ & 0624 & 1.0 & 60 & JMY \\
\hline 21 & 1 & $23-5-15$ & 0831 & 2.0 & 10 & JMY \\
\hline 21 & 2 & $30-5-15$ & 1032 & 4.0 & 12 & EKP \\
\hline 21 & 3 & $14-6-15$ & 0942 & 3.5 & 23 & MPN \\
\hline 21 & 4 & $25-6-15$ & 0742 & 1.0 & 40 & JMY \\
\hline 21 & 5 & $4-7-15$ & 0642 & 1.0 & 60 & JMY \\
\hline \multicolumn{7}{|c|}{ Bärsta, spring crop vårsäd } \\
\hline 22 & 1 & $16-6-15$ & 0910 & 2.0 & 35 & JMY \\
\hline 22 & 2 & $26-6-15$ & 0727 & 2.0 & 50 & MPN \\
\hline 22 & 3 & $4-7-15$ & 0839 & 0.0 & 70 & JMY \\
\hline 23 & 1 & $16-6-15$ & 0912 & 3.0 & 35 & MPN \\
\hline 23 & 2 & $26-6-15$ & 0649 & 3.0 & 50 & MPN \\
\hline 23 & 3 & $5-7-15$ & 0859 & 0.0 & 70 & JMY \\
\hline 24 & 1 & $17-6-15$ & 0805 & 2.5 & 30 & MPN \\
\hline 24 & 2 & $26-6-15$ & 0628 & 2.0 & 30 & MPN \\
\hline 24 & 3 & $5-7-15$ & 0922 & 0.0 & 70 & JMY \\
\hline
\end{tabular}




\section{Appendix 2}

Skylark observations and counting of possible predators during and after harvest on a surveyed silage field 2015, with an area of 50 hectares at Sörby estate, Kvismaren. (See also Photo 2.)

Observers: $\mathrm{JMY}=$ June Murray, EKP $=$ Elisabeth Kopp, MPN= Magnus Persson.

\section{June}

Harvest northern part. Weather: dry, sunny $(\sim 17$ degrees), wind from SW ( $8 \mathrm{~m} / \mathrm{s}$ at first, dropping to almost 0 by the end); start: 15.45 end: about 19.00 , with pause from 16.00 to 17.00 .

The farmers first cut the edges of the field and then drove away for about an hour. During this cutting skylarks were displaying in the neighbouring uncut field. In the pause between the cutting skylarks displayed over the still uncut part as well as over the cut part. Two skylarks landed in the cut part on top of the grass lying on the ground. They were not carrying food (probably). Also during the pause, three skylarks flew very quickly and flat above the ground over the still uncut part, crossing the cut part, flying into the neighbouring field where they met two more skylarks; they were chasing each other a little and went down to the ground.

While the harvest was going on (two machines simultaneously) gulls gathered, most of them staying close behind the machines, probably looking for insects. They only stayed longer on a spot further from the machines where a dead fawn was found.

Gulls and jackdaws were the first to arrive, foraging on the ground. At the very beginning of the harvest, one raven fought with the marsh harrier. The ravens meanwhile went on circling the field in the air and kept some distance. At one point one raven suddenly flew into the middle of the gulls, stealing a field mouse from them. Two hooded crows walked between jackdaws, too far away to see what they fed on. No predator was seen picking up or carrying away skylark chicks or other birds.

After the harvest the gulls were slowly leaving, just the jackdaws, crows and ravens stayed till later evening as well as the marsh harrier. After the harvest, one or two (could be double counted) skylarks were displaying completely over the harvested field, "ignoring" the corvids and gulls (EKP).

Areas where crows/gulls gathered immediately after cutting were checked, the first two of these on ridges where the blades had scraped vegetation away to expose soil. No evidence of nests/chicks destroyed or otherwise was found at these locations. At the third location a dead fawn was found.

Whilst cutting was still taking place a single skylark flew low and purposefully over the cut hay behind the tractor and landed in the still uncut area (it was not observed again). This is similar to observations made by EKP above.

One skylark recorded singing well after the harvest, whilst another sung in broken spells. (JMY)

Predators: Black headed gulls: 88. Common gulls: 2; herring gulls: 2; (gulls seemed more interested in insects and "small stuff"), about 30 jackdaws (same behaviour); one male Marsh harrier patrolling across the cut grass, hasn't been seen picking up birds though. 4 ravens circling, one is stealing a field mouse off the gulls. One raptor (probably black kite patrolling high up shortly over neighbour field but left quickly; Hooded crows: 2; Fox 1(evening) (EKP).

\section{June}

9.30-11.30. Overcast, dry, wind $0-2 \mathrm{~m} / \mathrm{s}$. Farmer was collecting the grass on neighbouring land. Observing from island in middle of field, three skylarks were heard and observed displaying, despite the grass having been cut (average height of grass now: $10 \mathrm{~cm}$ ). This was surprising in comparison to the previous year's study, when the field fell absolutely silent after the hay harvest. Two roe deer fawns found dead as result of harvest machines going through. Ground searched for evidence of destroyed skylark nests or chicks with areas where gulls and crows seen gathering searched with particular thoroughness. (MPN, JMY)

Predators seen at arrival: raven 1, marsh harrier 1, crow 5, black headed gulls 2. All of them flew as we approached, except the marsh harrier. This continued hunting throughout the period of observation. Marsh harrier observed eating small rodent.

\section{June}

Second southern part of harvest. Start: 10.00 hrs. End: between 12.30 and 13.00. This time it was only one machine harvesting. No skylarks were singing when we came to the field which is strange because the harvest had just started on one far off end of the field.

We could not find any nests even though we could see one skylark carrying food (caterpillar, probably Noctuidae) and obviously searching for its nest (12.02). It walked around slowly on the pile 
of hay and next to it, dropping the caterpillar a few times until it dropped it completely. After that we went out to look for its nest, turning around all the hay in this area, but we could not find it.

One to 3 skylarks were singing over the uncut part in the south (that strange clover-sheperd's purse field) during almost the whole harvest from 10:57 on until the machine was halfway finished with that part. Another one was singing over another part of the still uncut field. One skylark was singing partially over the already harvested field and partially over the not yet harvested field $(11: 48)$ until the machine approached it, then it quit. Two skylarks were observed flying out of the still uncut grass onto the harvested line closest by, sitting there shortly, flying very low back into the high grass whilst the harvest was still going on (no panic). Some skylarks (up to 8 ) were observed sitting around in the harvested parts (without food in the beak) looking around, not moving or moving very slowly, some of them randomly picking on the ground (foraging?). They seemed confused.

After the harvest was completed we stayed another 2 hours but no more skylarks could be heard anymore (may also be because they were never very active around that time of the day). Only two skylarks could be observed flying up flushed in front of or around the harvest machine. We guess that many skylarks flee by foot before the machine approaches or have flown off a long time before that as we couldn't see more fleeing (feel vibrations?).

Predators: 2 Marsh harriers after harvest, 1 during harvest (arrived at 11:33), 26 black headed gulls. Around 40 Jackdaws, 3 ravens (first one came in around 40 minutes after start of harvest when 1/4 of field was harvested, second one came after about 1 hour),2 herring gulls, 3 hooded crows, 1 kestrel (male 11:14), 4 buzzards (first two of them came around 10:45 o clock, the other two showed up at 11),1-2 common gulls fighting over a mouse or bird (close to the tree line, unlikely to be a skylark?) (11:51, JMY).Two ravens were picking up a mouse each (Arvicolinae, one of them for sure common vole because it was huge and fat), one of them at 11:20 o' clock (EKP+MPN). Black headed gull tried to carry of a vole but it was too heavy and it dropped it. The gull was followed by 10 other gulls but they didn't seem to be interested in the vole. One marsh harrier picked up another vole. No hunting success for kestrel or buzzards could be observed. Marsh harrier flew in between the gulls in the most freshly cut hay (MPN). 